\title{
Professor Hans Ludwig: Personal note
}

\author{
Hans Ludwig
}

Received: 5 July 2010 / Accepted: 6 July 2010 / Published online: 23 July 2010

(C) Springer-Verlag 2010

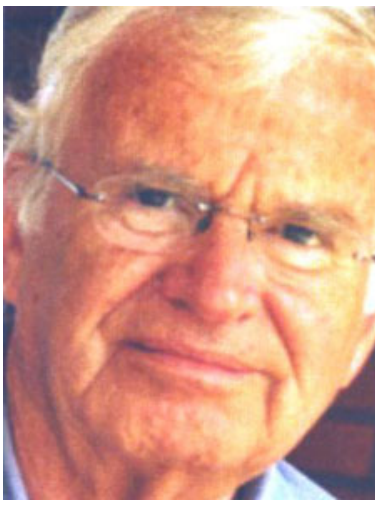

I am leaving the coordinating functions within the Editorial Board and transferring them into younger hands. Klaus Diedrich, head of the Department of Obstetrics and Gynecology of the Medical University in Lübeck, Germany, will take over. All the other Board members will-for the time being - stay in their functions. I am indebted to their sympathy and their support over the many years. The new Coordinating Editor, Klaus Diedrich, has my professional blessings and I am wishing him well, be prepared to assist in the near future by staying on as an Editor Emeritus of the Editorial Board, however, the final decisions in all daily matters will be taken by Klaus Diedrich from October 2010 onwards.

I have stayed with the journal for the duration of full 30 years, having formerly published many papers there myself. During the three decades, an abundant number of

H. Ludwig ( $\square)$

University of Basel, Basel, Switzerland

e-mail: prof.ludwig@bluewin.ch papers, submitted to us from everywhere, have passed the Editorial Board. We created connections with colleagues all over the world and I am thankful for the input from so many submissions. We always tried to keep the journal abreast of the scientific and clinical development in our discipline. We tried to be precise and fair when decisions have finally to be made. Our intention was always to meet them fast. My colleagues of the Editorial Board assisted with their wisdom and knowledge; the members of the Advisory Board, changing in the course of the years, have helped to review papers and include their knowledge from their respective subspecialities.

Above all, I feel obliged to express my warmest thanks to the many reviewers, most of them from abroad. They have contributed essentially to improve the manuscripts when necessary. The Impact Factor is rising, presently the amount of submissions borders on nearly 1,000 papers per year, and only less than of half of them can be printed. All contributors will know that there have to be some limitations. Some submissions being valuable and innovative by themselves could not be accepted out of mere space limitations. In the last decade, I tried to write personal letters to many authors who might be disappointed about the claim for revisions or had to reconcile themselves with an unfortunate decision. Never were those negative decisions made without serious and proper deliberation within the Board.

At a given time, even a long professional carrier is running out. The predecessors in my position, i.e. Albert Döderlein, Heinrich Martius, Carl Kaufmann, Karl-Günther Ober, mostly took on to work for the journal long after their active terms at their respective universities have come to an end. So did I. When I joined the Board (1980), I have been the chairman of the Department in Essen, afterwards of that in Basel and I stayed on post retirement from my active clinical work, until now. I will continue to keep a vigilant 
eye on this traditional periodical founded in 1870 in Germany. May it strive further on and maintain to be one of the international organs for the entire field of Gynecology and Obstetrics, reflecting the development of our discipline as it has always been the most noble aim of the journal's leaders.

Conflict of interest None. 